\title{
STABILITY-INDICATING HPLC ASSAY METHOD OF LOVASTATIN
}

\author{
R. Al-Masri and M. A. Al-Mardini
}

Department of Pharmaceutical Chemistry and Drugs Control, Faculty of Pharmacy, Damascus University, Damascus, Syria

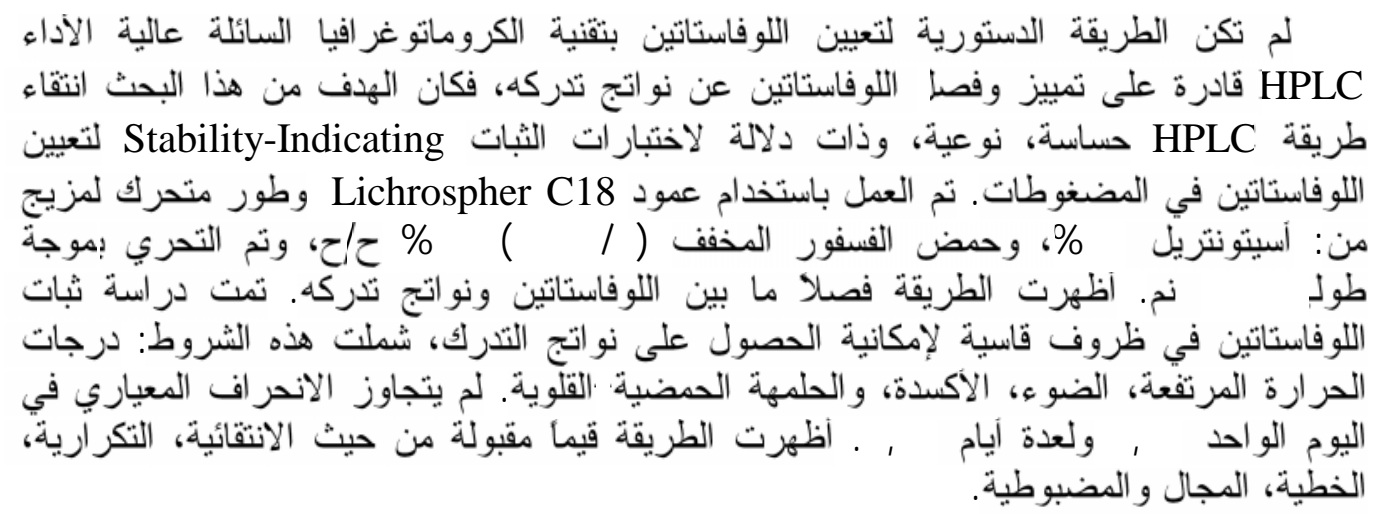

An HPLC assay method for determining of lovastatin in the presence of its degradation products was validated under acidic, basic, hydrogen peroxide, high temperature, and photo-

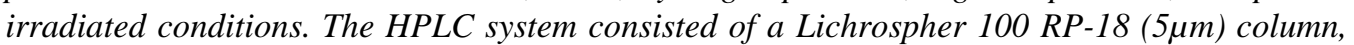
and a guard column of Lichro CART (150x 3.9) using a mobile phase of acetonitrile-phosphoric $\operatorname{acid}(0.1 \%)(50: 50, \mathrm{v} / \mathrm{v})$ with $U V$ detection at $238 \mathrm{~nm}$. The results indicate that the established assay method is suitable for stability measurements of lovastatin. From the stress treatments, lovastatin was determined to be sensitive to the light, acidic, and basic medium.

\section{INTRODUCTION}

Lovastatin:(1S,3R,7S,8S,8aR)-8-[2[(2R,4R)-4-hydroxy-6-oxotetrahydro-2Hpyran-2-yl]ethyl]-3,7-dimethyl-1,2,3,7,8,8ahexahydronaphthalen-1-yl (2S)-2-methylbutanoate.<smiles>CC[C@H](C)C(=O)O[C@H]1C[C@@H](C)C=C2C=CC(C)[C@H](CC[C@@H]3CC(O)CC(=O)O3)[C@H]21</smiles>
Lovastatin
It represents the first of a new class of cholesterol-lowering agents, the HMG-CoA reductase inhibitors, which are indicated for the treatment of primary hypercholesterolaemia. Lovastatin was also the first HMG-CoA reductase inhibitor acknowledged to slow coronary atherosclerosis. It was approved by FDA for the treatment of hypercholesterolaemia in August 1987. ${ }^{1-3}$

A sensitive, specific, and rapid determination of lovastatin was mentioned in USP. $25 .^{4}$ However, the applicability of this HPLC method on the samples containing photodegradants is still unclarified..$^{5-26}$ It is therefore desirable to study its stabilityindicating nature which may enable simultaneous detection of acid-induced, baseinduced, and photo-induced degradants of lovastatin. 


\section{MATERIALS AND METHODS}

\section{Chemicals}

Lovastatin standard was from World Health Organization (WHO). Acetonitrile, phosphoric acid, potassium phosphate monobase, and water for HPLC were from Merck (Darmstadt, Germany).

\section{HPLC Apparatus and Assay Conditions}

A SHIMADZU LC-10 AD liquid chromatograph equipped with a SPD-10AV Shimadzu UV-visible detector, a CTO-10A SHIMADZU column oven, a SIL-10 AD SHIMADZU auto injector, and a Merck Lichrospher $100 \mathrm{RP}-18(5 \mu \mathrm{m})(150 \times 3.9 \mathrm{~mm}$ i.d.) column equipped with a guard column of Lichro CART(4 x 125) were used with a mobile phase of acetonitrile-phosphoric acid $(0.1 \%)(50: 50, \mathrm{v} / \mathrm{v})$. The UV detector was set at $238 \mathrm{~nm}$ and a flow rate $3.0 \mathrm{ml} / \mathrm{m}^{4}$

Stress Treatment of Lovastatin in Acidic, Basic, hydrogen peroxide, high temperature, or photo-irradiated conditions.

Buffer was prepared by dissolving an amount of $1.3609 \mathrm{~g}$ of monobasic potassium phosphate in a $1000-\mathrm{mL}$ volumetric flask with distilled water and diluting to volume with it.

Dilution solution was prepared using acetonitrile and potassium phosphate buffer $0.01 \mathrm{M}$ in the ratio of $40: 60 \mathrm{v} / \mathrm{v}, \mathrm{pH}$ was adjusted to 4 with phosphoric acid.

An amount of $3 \mathrm{mg}$ of lovastatin was accurately weighed and placed in a $100-\mathrm{mL}$ volumetric flask. A concentration of 0.03 $\mathrm{mg} / \mathrm{mL}$ solution was prepared as a stock solution by adding the dilution solution to the marked volume.

Ten milliliters were taken from the stock solution and placed in a $100-\mathrm{mL}$ volumetric flask (this procedure was repeated five times) and each one was treated as follows to make each solution with $3 \mu \mathrm{g} / \mathrm{mL}$ concentration:

1- $20 \mathrm{~mL}$ of $0.5 \mathrm{~N} \mathrm{HCl}$ was added to the first flask then placed in boiling water for 60 minutes.

2- $20 \mathrm{~mL}$ of $0.5 \mathrm{~N} \mathrm{NaOH}$ was added to the second flask then placed in boiling water for 60 minutes.
3- $10 \mathrm{~mL}$ of $10 \% \mathrm{H}_{2} \mathrm{O}_{2}$ was added to the third flask then shacked thoroughly and let in room temperature for 30 minutes.

4- The fourth flask was incubated at $60^{\circ}$ temperature for 7 days.

5- The fifth flask was irradiated under a Hanovia 200-W high-pressure mercury lamp for 7 days. The distance of the light source to the sample was maintained at 25 $\mathrm{cm}$.

The acidic solution was neutralized with $20 \mathrm{~mL}$ of $0.5 \mathrm{~N} \mathrm{NaOH}$, while the basic solution was neutralized with $20 \mathrm{~mL}$ of $0.5 \mathrm{~N} \mathrm{HCl}$, then the five samples were diluted with distilled water to the mark. The samples were then subjected to HPLC analysis. Each of the above 5 stress treatments was tested in triplicates. ${ }^{27}$

\section{RESULTS AND DISCUSSION}

\section{Degradation of Lovastatin}

The chromatograms of lovastatin degraded in acidic, basic, hydrogen peroxide, high temperature, and photo-irradiated conditions are shown in Figures 1,2,3,4,5, and 6. After stress treatment under acidic, basic, and hydrogen peroxide, the amounts of lovastatin remained were $15.5 \%, 14.9 \%$ and $17.3 \%$, respectively whereas under $\mathrm{Hg}$ lamp irradiation and $60^{\circ}$ temperature, they were $55.4 \%$ and $57.7 \%$ respectively. The results clearly show that lovastatin is more labile to photoirradiation than to high temperature treatment.

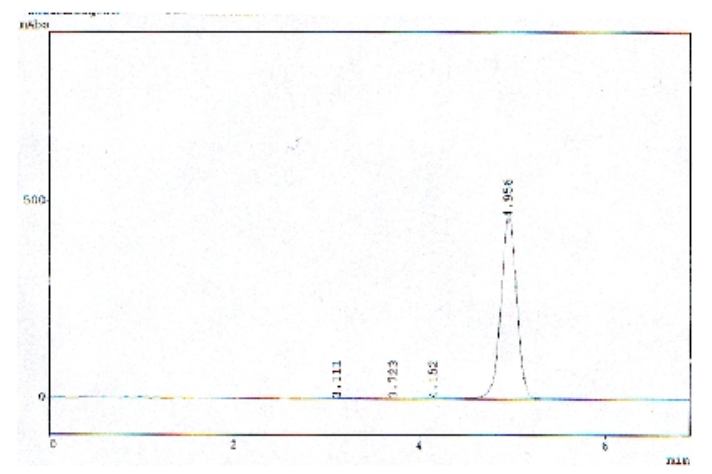

Fig. 1: HPLC chromatogram of standard solution of lovastatin. 


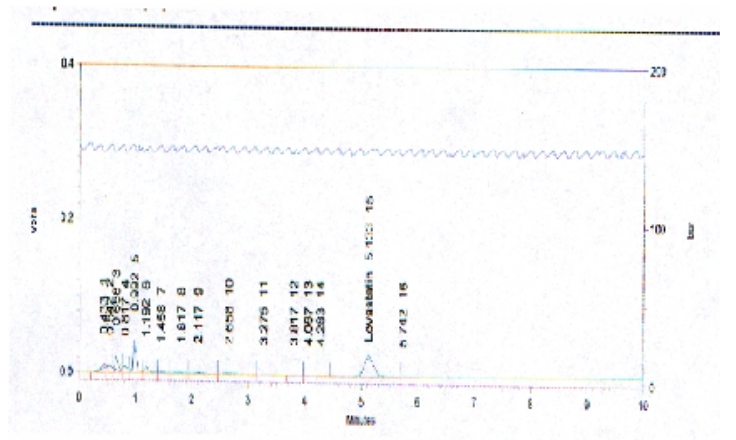

Fig. 2: HPLC chromatogram of degraded solution of lovastatin under acidic conditions.

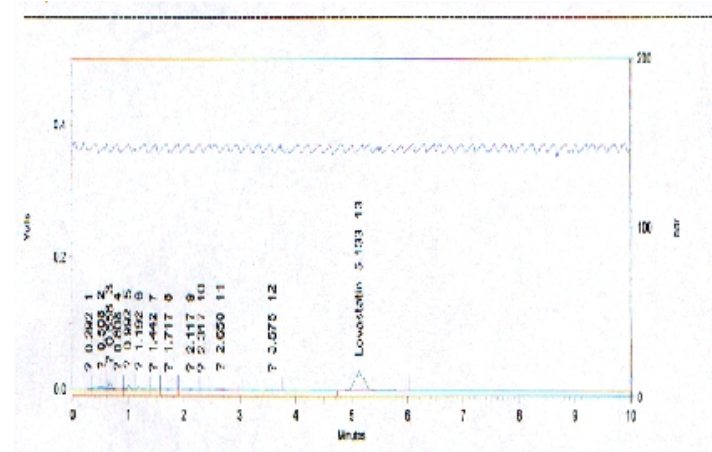

Fig. 3: HPLC chromatogram of degraded solution of lovastatin under basic conditions.

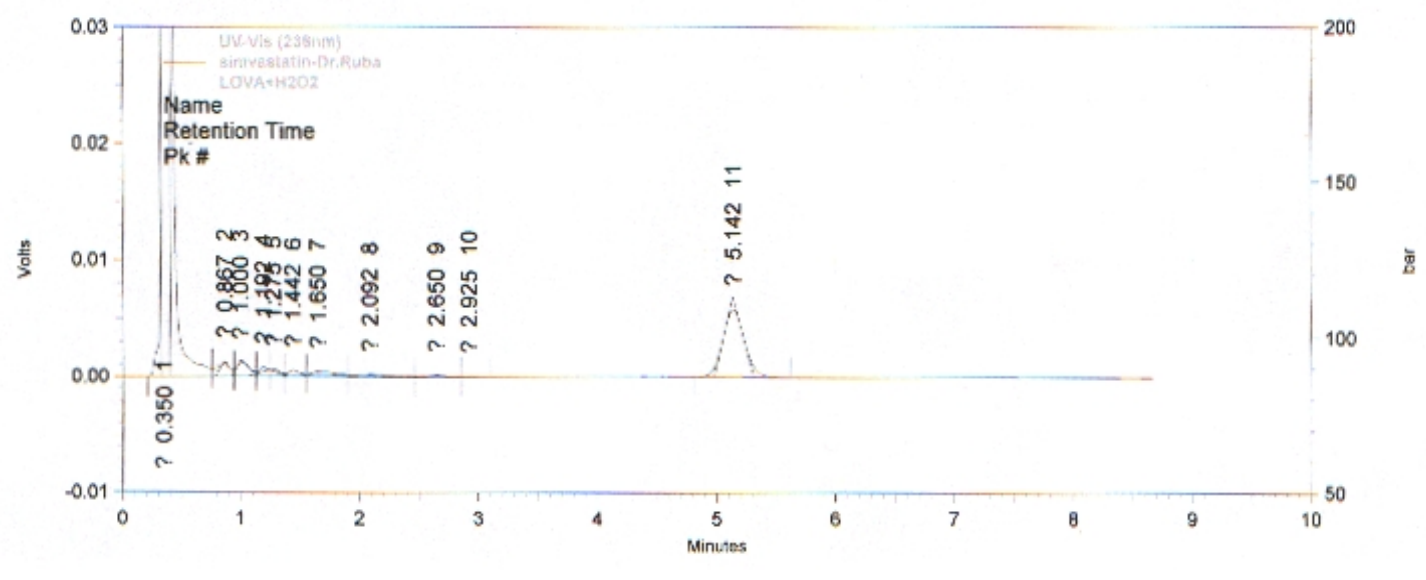

Fig. 4: HPLC chromatogram of degraded solution of lovastatin under hydrogen peroxide conditions.

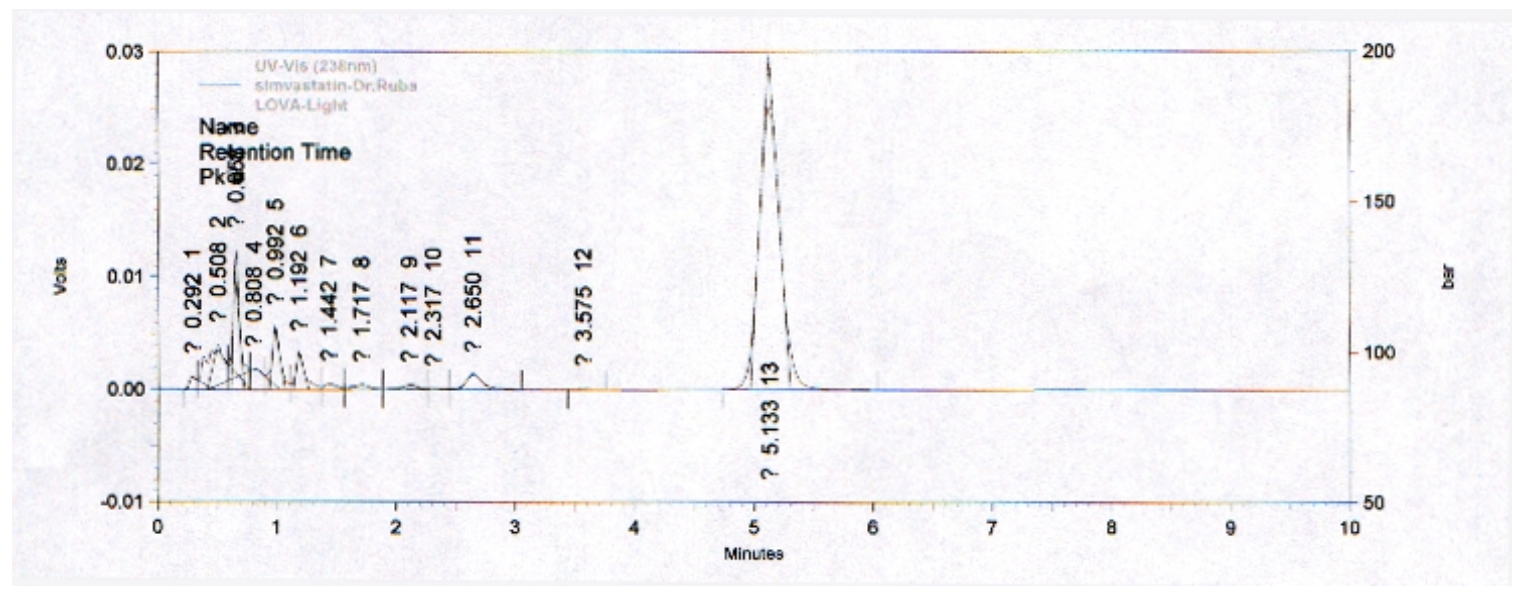

Fig. 5: HPLC chromatogram of photodegraded solution of lovastatin by a high-pressure mercury lamp for 7 days 


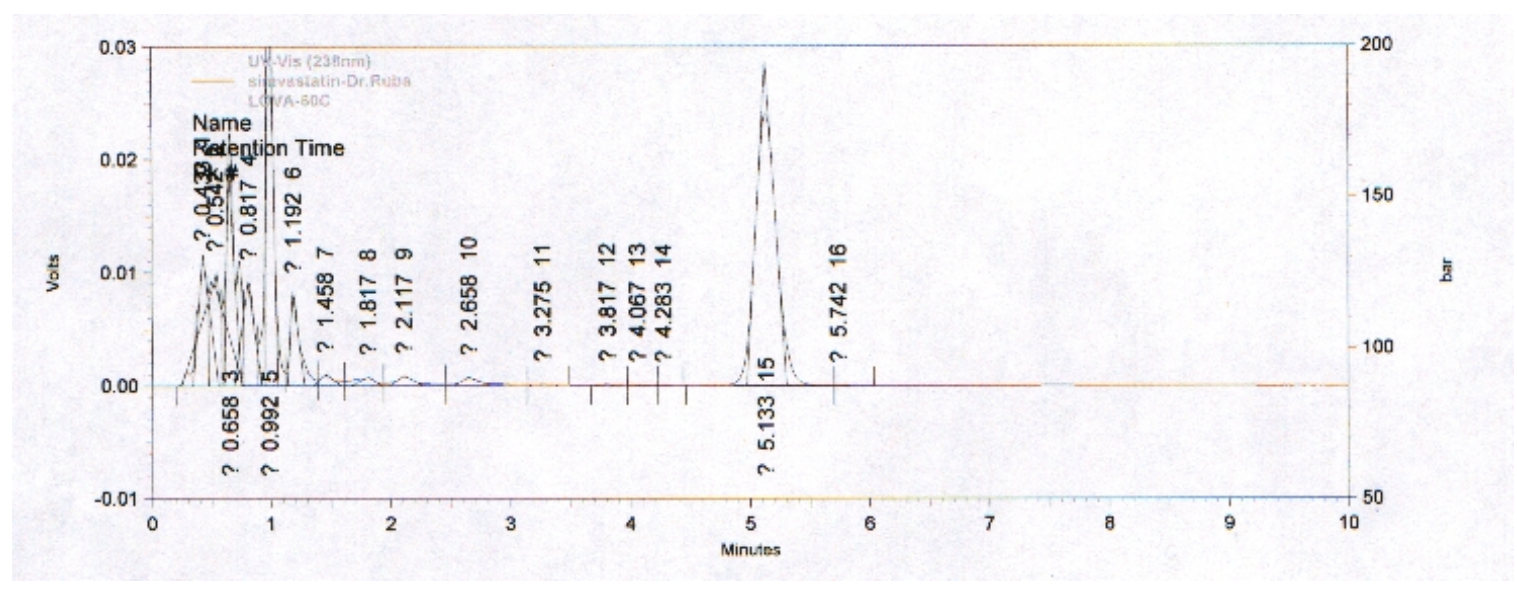

Fig. 6: HPLC chromatogram of degraded solution of lovastatin at $60^{\circ}$ temperature for 7 days.

\section{Validation of HPLC Method}

A quantitation method must selectively separate the parent drug from its potential impurities and degradants. ${ }^{28-37}$ Our established method satisfies the system suitability criteria, peak integrity, and resolution between the parent drug and degradants. The results clearly indicate that the established assay method has good selectivity and specificity for quantitation and stability measurements of lovastatin.

The linearity of the calibration curve was checked over the range of 1 to $3 \mu \mathrm{g} / \mathrm{mL}$ in a diluted solution. The calibration curve was constructed by plotting the lovastatin response area ratio vs. concentration. The calibration curve for lovastatin is rectilinear in the concentration range studied. The related coefficient of the linear regression analysis is $r^{2}=0.9997$. The results of linear regression give the equation $\mathrm{y}=0.9981 \mathrm{x}+0.0058$.

The intraday (Table 1) and interday (Table 2) standard deviations (S.D.) of six replicate determination for six consecutive days at the usual working concentrations of 1.0 to 3.0 $\mu \mathrm{g} / \mathrm{mL}$ were among 0.007 and 0.220 with $\mathrm{CV}$ between $0.234 \%$ and $1.698 \%$ for the former; 0.019 to 0.098 with CV between $1.269 \%$ and $3.821 \%$ for the latter. The accuracy of the method as referred by recovery tests at five concentrations $(1.5,2.25,3,3.75$, and 4.5 $\mu \mathrm{g} / \mathrm{mL}$ ), was determined to be $99.47 \%$, $97.87 \%, \quad 99.8 \%, \quad 101.1 \%$ and $98.13 \%$, respectively, indicating good accuracy for the assay method. Clearly, the assay method is reliable and applicable for stability assessment of lovastatin degraded under photo-irradiated condition.

Table 1: Intraday analytical precision and accuracy for lovastatin $(n=6)$.

\begin{tabular}{|c|c|c|c|c|c||}
\hline $\begin{array}{c}\text { Conc. } \\
(\mu \mathrm{g} / \mathrm{mL})\end{array}$ & 1 & 1.5 & 2 & 2.5 & 3 \\
\hline $\mathrm{Y} 1$ & 1.002 & 1.472 & 2.014 & 2.503 & 2.997 \\
\hline $\mathrm{Y} 2$ & 0.982 & 1.480 & 2.025 & 2.510 & 2.986 \\
\hline $\mathrm{Y} 3$ & 1.009 & 1.529 & 2.011 & 2.480 & 2.991 \\
\hline $\mathrm{Y} 4$ & 0.995 & 1.492 & 2.013 & 2.495 & 3.005 \\
\hline $\mathrm{Y} 5$ & 0.988 & 1.475 & 2.042 & 2.486 & 2.989 \\
\hline $\mathrm{Y} 6$ & 1.031 & 1.505 & 2.009 & 2.479 & 2.993 \\
\hline Mean & 1.001 & 1.492 & 2.022 & 2.492 & 2.994 \\
\hline SD & 0.017 & 0.022 & 0.013 & 0.012 & 0.007 \\
\hline CV $(\%)$ & 1.698 & 1.475 & 0.643 & 0.482 & 0.234 \\
\hline
\end{tabular}

Table 2: Interday analytical precision and accuracy for lovastatin $(n=6)$.

\begin{tabular}{||c|c|c|c|c|c||}
\hline $\begin{array}{c}\text { Conc. } \\
(\mu \mathrm{g} / \mathrm{mL})\end{array}$ & 1 & 1.5 & 2 & 2.5 & 3 \\
\hline $\mathrm{Y} 1$ & 1.002 & 1.472 & 2.014 & 2.503 & 2.997 \\
\hline $\mathrm{Y} 2$ & 0.968 & 1.498 & 1.981 & 2.575 & 3.101 \\
\hline $\mathrm{Y} 3$ & 0.982 & 1.525 & 2.170 & 2.498 & 3.043 \\
\hline $\mathrm{Y} 4$ & 1.015 & 1.489 & 1.915 & 2.539 & 2.981 \\
\hline $\mathrm{Y} 5$ & 0.979 & 1.486 & 1.993 & 2.517 & 2.909 \\
\hline $\mathrm{Y} 6$ & 1.024 & 1.514 & 2.019 & 2.479 & 2.825 \\
\hline Mean & 0.995 & 1.497 & 2.015 & 2.519 & 2.976 \\
\hline SD & 0.020 & 0.019 & 0.077 & 0.034 & 0.098 \\
\hline CV $(\%)$ & 2.010 & 1.269 & 3.821 & 1.349 & 3.293 \\
\hline
\end{tabular}




\section{REFERENCES}

1- A. W. Alberts, Cardiology., 77, 14 (1990).

2- G. Mantell, Therapie., Mar-Apr, 47, 161 (1992).

3- W. H. Frishman and R. C. Rapier, Med. Clin. North. Am., 73, 437 (1989).

4- The United States Pharmacopoeia, $25^{\text {th }}$ Revision, United States Pharmacopeial Convention, Inc., Rockville, MD, (2002).

5- H. Ochiai, N. Uchiyama, K. Imagaki, S. Hata and T. Kamei, J. Chromatogr. B. Biomed. Sci. Appl., 694, 211 (1997).

6- M. G. Orkoula, C. G. Kontoyannis, C. K. Markopoulou and J. E. Koundourellis, J. Pharm. Biomed. Anal., 35, 1011 (2004).

7- L. Wang and M. Asgharnejad, J. Pharm. Biomed. Anal., 21, 1243 (2000).

8- H. Cheng, S. C. Sutton, J. D. Pipkin, G. M. Zentner, J. D. Rogers, J. I. Schwartz, Y. B. Mitchel, K. Grasing, M. S. Schwartz, R. D. Amin, et al, Pharm. Res., 10, 1683 (1993).

9- M. S. Siamak, N. Moazami, S. Haghighi, F. A.Mohseni, S. Mirdamadi, and M. R.Bakhtiari, Iran. Biomed. J., 7, 29 (2003).

10- R. Luo, K. Sun, S. Xie, Y. Han, Wei. Sheng. Yan. Jiu., 32, 157 (2003).

11- J. T. Strode, L. T. Taylor and A. L. Howard, J. Pharm. Biomed. Anal. 20, 137 (1999).

12- L. Tan, L. L.Yang, X. Zhang, Y. S.Yuan and S. S.Ling, Se. Pu., 18, 232 (2000).

13- M. K. Srinivasu, A. N. Raju and G. O. Reddy, J. Pharm. Biomed. Anal., 29, 715 (2002).

14- M. J. Morris, J. D. Gilbert, J. Y. Hsieh, B. K. Matuszewski, H. G. Ramjit and W. F. Bayne, Biol. Mass. Spectrom., 22, 1 (1993).

15- S. Erturk, A. Onal and S. Muge Cetin, J. Chromatogr. B. Analyt. Technol. Biomed. Life. Sci., 793, 193 (2003).

16- L. Y. Ye, P. S. Firby, M. J. Moore, Ther. Drug. Monit., 22, 737 (2000).

17- S. J.Rajh, S. K.Borut, B. Trukelj and B. F.Vreer, Croat. Chem. Acta., 76263 (2003).

18- M. M. Mabrouk, A. A. Habib and H. M. El-Fatatry, Bull. Fac. Pharm., Cairo Univ., 36, 59 (1998).
19- A. A. Habib and M. M. Mabrouk, Zag. J. Pharm. Sci., 2, 1 (1993).

20- C. M.Riley, Xenobiotica., 17, 365 (1987).

21- R. L. Hagan, Am. J. Hosp. Pharm., 1; 51, 2162 (1994).

22- X. S. Miao and C. D. Metcalfe, J. Chromatogr. A., 23, 998, 133 (2003).

23- R. E. B. Astigarraga and G. D. Nucci, "Standard Operating Procedures", Institute of Biomedical Sciences USP, Brazil (2002).

24- J. C. Berridge, Impurities in drug substances and drug products: new approaches to quantification and qualification. 14 (1-2), 7-12 (1995).

25- R. Grahek, D. Milivojevic, A. Bastarda and M. Kracun, J. Chromatogr. A., 918, 319 (2001).

26- C. K. Markopoulou and J. E. Koundourelllis, J. Pharm. Biomed. Anal., 33, 1163 (2003).

27- A. Xu. Quanyun and A. T. Lawrence, "Stability-Indicating HPLC Methods for Drug Analysis" Pharmaceutical Press London, UK, $2^{\text {nd }}$ Ed. (2003).

28- M. Bakshi and S. Singh, J. Pharm. Biomed. Anal., 28, 1011 (2002).

29- Y. Wu, Biomed. Chromatogr., 14, 384 (2000).

30- T. Sugiyama, R. Matsuyama, S. Usui, Y. Katagiri and K. Hirano, Biol. Pharm. Bull., 23, 274 (2000).

31- T. D. Wilson, J. Pharm. Biomed. Anal., 8, 389 (1990).

32- G. Szepesi, M. Gazdag and K. Mihalyfi, J. Chromatogr., 464, 265 (1989).

33- D. Dadgar and P. E. Burnett, J. Pharm. Biomed. Anal., 14, 23 (1995).

34- M. Heinanen and C. Barbas, J. Pharm. Biomed. Anal., 24, 1005 (2001).

35- D. S. Hayward, S. R. Zimmerman and D. R. Jenke, J. Chromatogr. Sci., 27, 235 (1989).

36- G. S. Clarke, J. Pharm. Biomed. Anal., 12, 643 (1994).

37- E. C. Chan, P. Y. Wee and P. C. Ho, Clin. Chim. Acta., 288, 47 (1999). 